\title{
Evaluation and comparative analysis of stress and deformations in seismic hazard zones in Bulgaria and adjacent lands
}

\author{
Valentina Protopopova*,1, Emil Botev ${ }^{1}$ \\ (1) Department of Seismology and Seismic Engineering, National Institute of Geophysics, Geodesy and Geography \\ Bulgarian Academy of Sciences
}

Article history: received February 14, 2019; accepted November 27, 2019

\begin{abstract}
In this paper an attempt to elucidate the geodynamic situation in Bulgaria and adjacent lands from a seismological point of view is proposed. The fault plane solutions of 418 earthquakes and corresponding stresses and deformations are also analyzed. For the purposes of the quantitative stress and strain modeling, a seismic zonation is carried out and the Bulgarian territory and surroundings are divided in nine seismic hazard zones. The main seismological and focal mechanisms characteristics for each zone are presented. The stress tensors for the zones/fault systems are calculated by inversion of the focal mechanisms data using the technique of Gephart [1990]. The released strain is computed by means of the moment tensors of focal mechanisms according to the relation of Kostrov [1974]. In general, the obtained mean strain tensors show some agreement with the calculated mean stresses. Several local discrepancies and the whole geodynamic situation are analyzed in the light of some present tectonic hypotheses. On the basis of the analysis of the seismicity, stress and deformation on the territory of North Balkans are presented.
\end{abstract}

Keywords: Earthquakes, Fault plain solutions, Stress, Deformations, Geodynamic, Tectonics.

\section{Introduction}

The earthquake sources and the environment in which seismic waves propagate are characterized by their hidden and inaccessible nature. The determination of the physical properties of the source determines the processes of excitation of the waves and how seismic energy is emitted. The types of the tectonic faults can be defined by determining the source mechanisms. Information about the geodynamic environment can be obtained from the detailed study of the physical properties of various earthquakes and the environment in which the seismic waves propagate.

The present tectonic structure of the Balkans is a result of the tectonic processes during the geological times mainly from Trias to Quaternary (Alpine folding). Three structural complexes are identified as a Pre-Cambrian (Archaic and Proterozoic), Caledonian-Hercynian and Alpine [Zagorchev 1992,1996]. The Alpine evolution of the observed area is still subject to many controversial interpretations.

In a classical interpretation, the Macedono-Rhodopian zone (as a part of the Traco-Anatolian global plate) is 


\section{Valentina Protopopova et al.}

considered to be a stable inner massif between the Alpine chain (Balkanides), to the north, and the South Alpine orogenic belt (Dinarides and Hellenides), to the south. The recent activity of the inner Macedono-Rhodopian massif is explained with the interaction between these two bounding orogenic belts [Bonchev, 1982].

The recent studies based on plate tectonics model [Zagorchev, 1992, 1996; Tzankov and Nikolov, 1998] consider the Macedono-Rhodopian zone as part of the southern margin of the Eurasian plate. This area was affected in the past by the sea-floor opening of the Thetys Ocean between the Eurasian and African plates, which led to the formation of several microplates. The northern margin of Africa acted as a passive one, while the southern border of Eurasia acted as an active continental margin. The boundary between these two margins, at the beginning of the Alpine evolution, is currently represented by the Vardar-Izmir-Ankara ophiolitic zone.

The Alpine evolution of the Central Balkans consists of several important compressive phases in Late Triassic, Early and Late Cretaceous, and Earliest Miocene times. Relicts of Paleozoic and pre-Paleozoic structures were reactivated and included into the Alpine structures, and tectonic units from the older orogens were welded into the younger ones as a "mosaic" pattern [Zagorchev, 1996]. During Earliest Miocene (or the Latest Oligocene), the Ionian zone was folded and thrusted onto the pre-Apulian zone, forming the convergent limit of an Ionian arc. The Neotectonic phase started in the Late Miocene and continued during the Pliocene and the Quaternary. It was characterized by a dominant sub horizontal extension with normal faulting and blocks separation. The young Alpine mountains (Balkanides, Dinarides, and Hellenides) were uplifted and became the neotectonic morphostructureboundaries of the Central Balkan region with the Danubian (or Moesian) and Ionian basins.

The contemporary tectonic environment in the area is characterized by a complex geological structure and geodynamics, caused by the collision of the Arabic, Anatolian and African plates with the Eurasian [McKenzie 1970; Jackson and McKenzie 1984, 1988; Jackson 1992, 1994; McClusky et al., 2000]. They suggest the existence of an Aegean plate that moves at a different speed from that of the Anatolian plate and a north-south extension zone in Western Turkey.

Bulgaria is located in the northern part of the Balkan Peninsula. The territory of Bulgaria is characterized by a high seismic hazard, the assessment is based on the large number of earthquakes, as the stronger ones had significant catastrophic consequences in the past. At present, the higher magnitude earthquakes expose an even greater risk of destructive consequences due to the higher degree of urbanization of our lands [Tsenov and Botev, 2007]. The earthquake activity on northern Balkan peninsula is proof for recent geodynamic movements in the region. The study of seismicity, source mechanisms, Earth crust stress, deformations and geodynamics, seismic zoning on the territory of Bulgaria and adjacent lands have scientific and economic significance. Such studies are necessary and important as they can serve as the basis for assessing seismic hazard and refining seismic building standards in each area.

\section{Seismic zoning and focal data}

On the basis of the geological and geodynamical characteristics, Bulgaria is subdivided into main structural provinces, with specific tectonic and neotectonic features [Bonchev et al., 1982; Zagorchev, 1992]. The tectonic provinces are (from the north to the south): Carpathians (Carpathian mountain range), Moesian platform (Moesian region, Danube plain), Balkanides (Fore-Balkan and Stara Planina), Srednogorie, Rhodopian massif, Struma (Krupnik), and Serbo-Macedonian massif.

In Figure 1418 solutions for focal mechanisms of stronger earthquakes are presented, for the period April 1928 - March 2018 and their distribution into nine seismic zones. The zoning presented in Figure 1 is similar to that proposed by Botev [2000], suitable to a specific seismogenic and seismic stress pattern characteristics.

In Figure 2 the nine tectonic provinces of the northern part of the Balkan peninsula are schematically presented. The northern part of the observed area consists of four seismic zones (zonation is presented on Figure 1). The Vrancea zone (Z1) is located on Romanian territory. The stronger earthquakes in the Vrancea zone are causing serious macro-seismological effect on the Bulgarian territory. The last strong earthquake happened on March 4, 1977, with magnitude 7.4, affected Svishtov city (Bulgaria), where industrial and residential buildings were destroyed and more than 100 casualties were reported. The Vrancea zone includes a part of the Southern Carpathians belt and the Focsani Basin (the Precarpathian Depression, Figure 1, 2). Southern Carpathians is a complex orogen of Paleogene-Neogene age and is thrusting considerably eastwards [Bonchev, 1982]. 


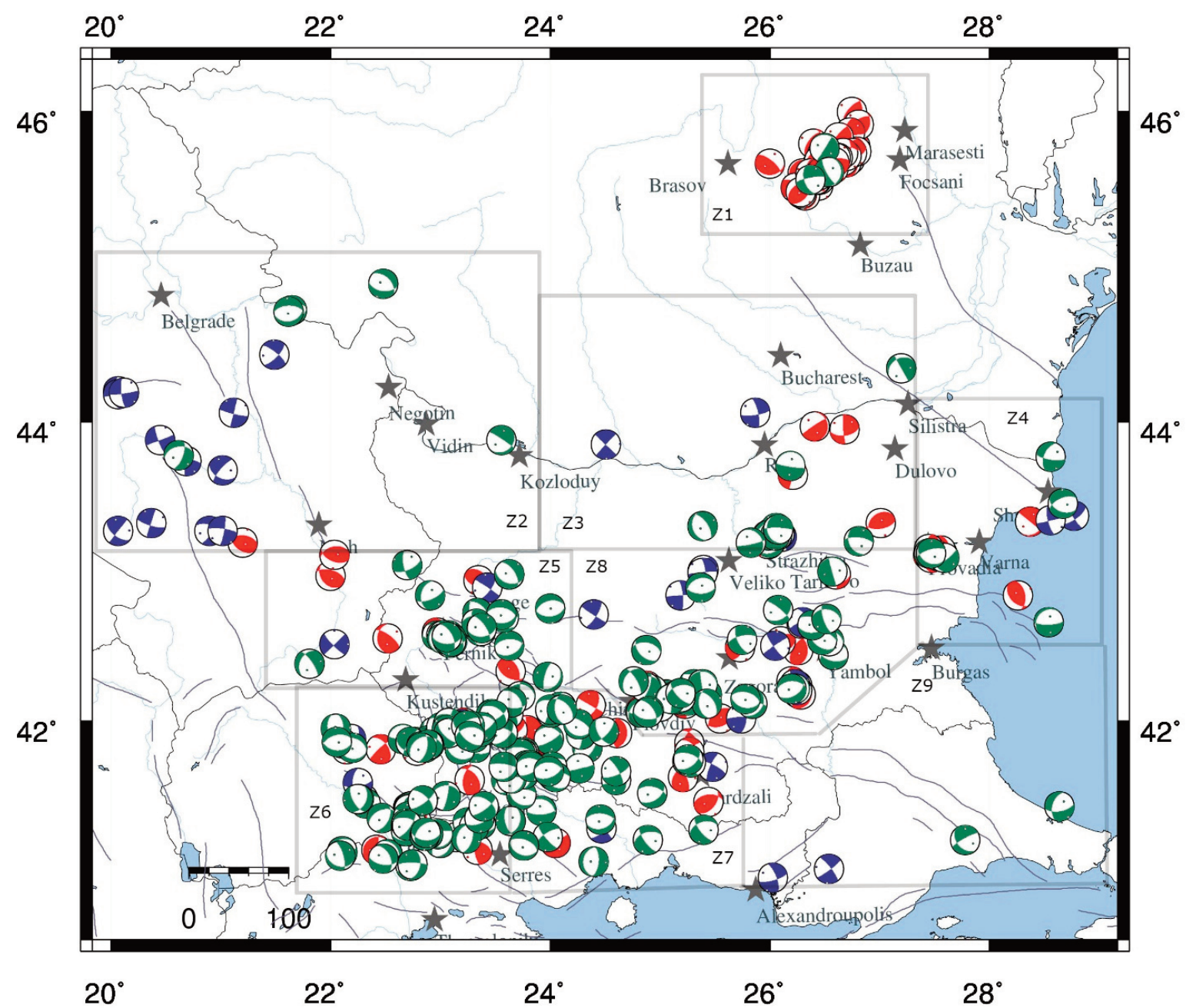

Figure 1. The distribution of 418 focal mechanisms in Bulgarian territory and adjacent lands. Z1 - Z9 - seismic zones, described in the text: Z1 - Vrancea (Romania); Z2 - Negotin (Serbia/North-Western Bulgaria); Z3 - Gorna Oryahovitsa zone; Z4 - North-Eastern Bulgaria; Z5 - Sofia seismic zone; Z6 - Struma river (South-Western Bulgaria); Z7 - Rodopie sesmic zone; Z8 - Maritsa seismic zone, Z9 - Burgas seismic zone. Green color - normal faulting; Red color - Thrust faulting; Blue color - Strike-slip faulting. The tectonic map: Barrier et al. [2004], Georgiev et al. [2007].

The Negotin zone (North-Western Bulgaria, Z2, Figure 1) is characterized by very low seismicity on Bulgarian and Romanian territory and significantly higher activity on the Serbian territory. Two stronger earthquakes happened in 1893 and 1895, estimated respectively with magnitudes $M=6.6$ and $M=6.0$, caused a small macroseismic impact on Bulgarian territory [Vatsov, 1902]. The earthquake of 1922 with $M=6$ also had macroseismic effects on the territory of Bulgaria [Grigoriva et al., 1979]. The zone includes a part of the Southern Carpathians belt, located in North-Western Bulgaria, and northern part of the Kraishte zone and the Serbo-Macedonian massif (Figure 1, 2).

The Gorna Oryahovitsa zone (Z3, Figure 1, 2) and the North-Eastern Bulgaria (Z4) are located on the southern part of the Moesian Platform. The Moesian platform is stretched in the east-western direction for about $500 \mathrm{~km}$ [Bonchev, 1982]. The platform represents an epi-Baikalian structure with two geological complexes. The lower complex is represented by fractured, highly tectonized Paleozoic-Triassic formations. The upper sedimentary complex lies almost horizontally over the lower complex with a stratigraphic and an angular unconformity. The Moesian platform is the most stable part of the studied region during Alpine times. Three main parts of the platform are distinguished on the territory of Bulgaria: Lom depression in the western part (the border between $\mathrm{Z} 2$ and Z3), North-Bulgarian arch swell in the eastern part (situated in Z4), and one median part between them with slight slope to the North-West (situated in Z3). 


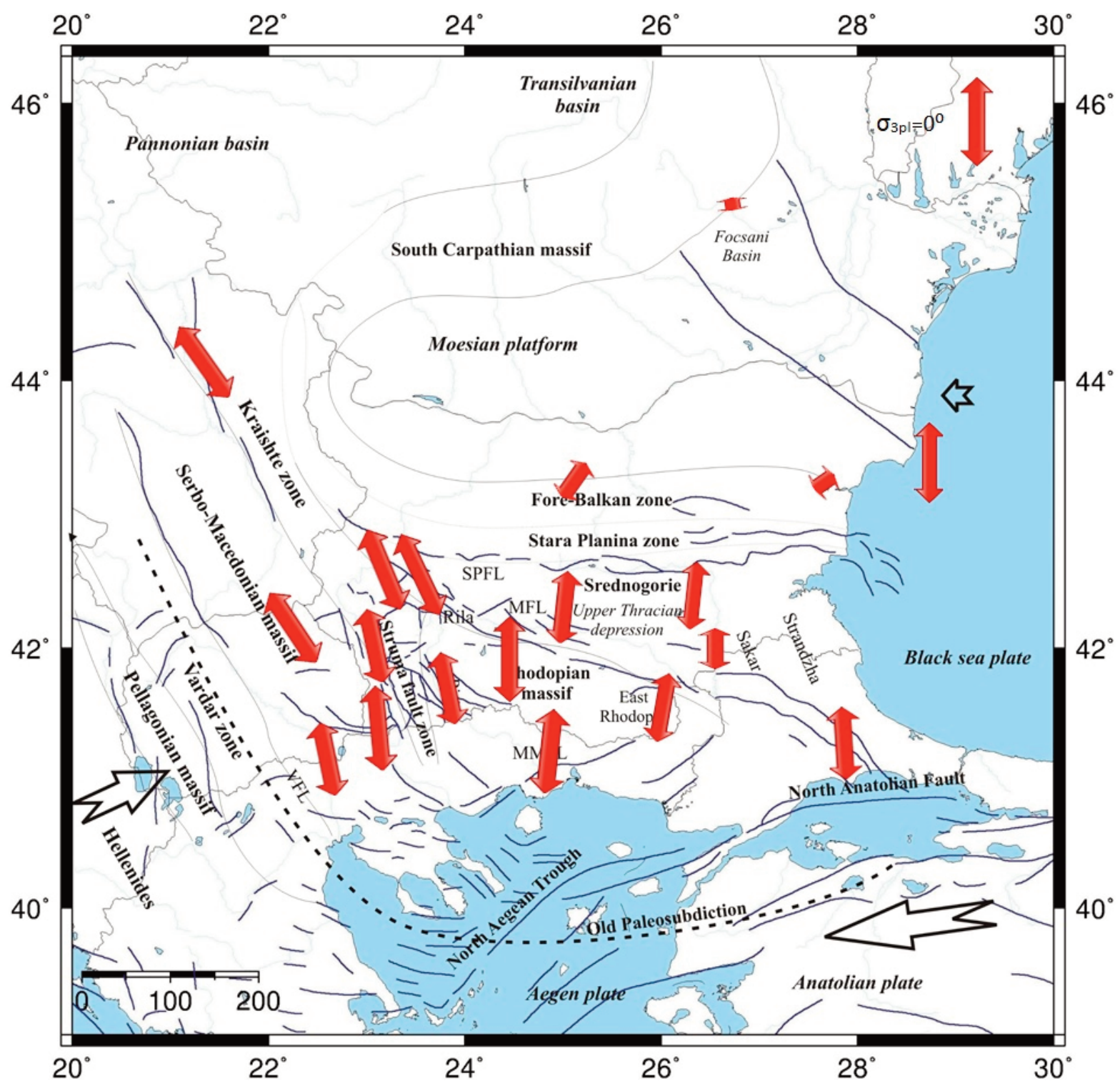

Figure 2. The horizontal projections of the extensional stress rate (red arrows - extension - $\sigma_{3}$. from Table 1) obtained by seismological data, white arrows present the movement of the tectonic blocks. The tectonic map including main structural provinces is described in the text. SPFL - Stara Planina fault, MFL-Martitsa fault, VFL - Vardar fault.

The strongest present event in the Gorna Oryahovitsa zone with available focal mechanism happened in 1986, with magnitude M=5.7 in the Strazhitsa fault system (Christoskov et al., 1988), followed by long aftershock activity.

Three devastating historical earthquakes with defined macroseismic magnitude $M>7.0$ are documented in the North-Eastern Bulgaria (Z4), at the present-day cities of Kavarna and Varna (on the northern Black Sea coast of Bulgaria), during the first century BC, 543 AD and 1444 [Grigorova et al., 1979; Christoskov et al., 1979].

The Southern part of Bulgaria consists of four high seismic zones with the Balkanides as border between North and South Bulgaria - Sofia (Z5) and Maritsa (Z8) in Central Bulgaria, Struma river (South-Western Bulgaria, Z6), Rhodope (Z7) in the South-Western Bulgaria, and aseismic Burgas zone (Z9) in the south-eastern part.

The Balkanides (the Fore-Balkans and Stara Planina, Figure 2) are located to the South of the Moesian plate. They represent a fold-thrust belt, which was essentially formed in Paleogene times. According to their morphotectonic structure they are subdivided into three secondary blocks: Western, Central, and Eastern 
Balkanides. The Western Balkanides are north-west - south-east oriented with considerable north-east vergent folding, while the Central and Eastern Balkanides are east-west oriented with smaller vergence to the north.

The Srednogorie structural province is oriented north-west - south-east in its western part, while its central and eastern parts are oriented east-west [Bonchev, 1982, Figure 2]. The Srednogorie length is about $500 \mathrm{~km}$ and its width varies between $30-40 \mathrm{~km}$ in the western part and up to $80 \mathrm{~km}$ in the eastern part. This zone is surrounded by the Balkanides to the north and Rhodopies to the south, by the Quaternary active Stara Planina and Maritza faults. The Srednogorie represents an Alpine paleo rift of a considerably complex structure, mainly formed as a volcanic arc in Late Cretaceous times. It is characterized by intensive magmatism and several main horst-graben structures are formed. These main structures are arranged from west to east as follows: The Sofia depression area, the Ihtiman horst block (situated in Z5), the Upper Trachian depression, the Central Srednogorie horst belt, the Jambol depression, the Sakar horst blocks (situated in Z8) and the Strandzha horst blocks (situated in Z9).

The seismic activity in Sofia seismic zone (Z5, Figure 1) is mainly associated with the Sofia graben. It is known with three strong historical earthquakes (magnitude around $6.0-6.5$ ), occurred in the mid-15th century, in 1818 and the strongest one in 1858 with magnitude $M=6.5$ [Christoskov et al., 1979]. The strongest present event in Sofia seismic zone happened near Pernik city (on Pernik fault) in 2012, with Mw=5.6.

The main morpho-structure in Struma seismic zone (Z8) is the Upper Thracian depression, the biggest syncline within the territory of Bulgaria (Figure 1,2). The seismic activity is mainly associated with the Maritza and Tundzha fault systems, but since 2011 the moderate magnitude seismic activity has increased in the Monastery uplifts fault system. Two strong events $(M=6.8$ and $M=7.0)$ happened in the Upper Thracian valley (along Maritsa fault system, Z8), in 1928, caused ruptures of more than $100 \mathrm{~km}$ on the earth surface. The strongest event of the Tundzha river fault system, in the eastern part of the Maritsa zone happened in 1909, with magnitude $\mathrm{M}=5.9$.

The Rhodopies massif (Z7, Figure 1) is located south to the Srednogorie zone and is the largest fragment of the former Macedono-Rhodopian massif [Bonchev, 1982, Figure 2]. It consists of several structural units: the allochtonous East Rhodopie unit, the autochtonous Central Rhodope, and Pirin and Rila mountains to the west and north-west. The oldest Pre-Cambrian metamorphic rocks are divided into two metamorphic complexes: the lower ultra-metamorphic complex is at Archean age, while the upper complex is referred to the Proterozoic age. The structure of the Rhodopiean massif is complicated, with a number of second-order horsts and grabens.

The seismic activity in Rodopie zone is mainly associated with the Chepino, Dospat, Devin and Ardino depression fault systems. The strongest earthquakes in the $20^{\text {th }}$ century are those of 1905 (M=5.4) and 1977 $(\mathrm{M}=5.3)$. Two strong historical earthquakes occurred in 1829 [magnitudes 6.9 and 7.3 according to Papazachos et al., 2000] along the southern border of the zone, in Greece.

The Struma lineament zone (Z6, Figure 1, 2) is located to the west of the Rhodopies. It is a structurally very complex zone associated with the Struma river valley (north-south direction), which divides the Rhodopiean massif from the Serbo-Macedonian massif [Bonchev, 1982]. According to its morphotectonic characteristics, the Struma zone is subdivided into the northern Krupnik and the southern Struma subzones. There are many Phanerozoic (Post-Cambrian) formations in this lineament bundle zone, but the Alpine formations are much more expressed. The southern part is affected by the greatest neotectonic activity, with vertical movements up to $3.5 \mathrm{~km}$, along the faults that separate some local grabens and the Rila and Pirin horst blocks (the border between Z6 and Z7). The Osogovo, Ograzhden and Belasitza horsts are part of the Serbo-Macedonian massif positioned in the south-western part of the studied area. The horsts are made up mainly of pre-Cambrian metamorphic complexes.

The strongest event in Bulgaria (Ms = 7.8) occurred in Struma zone on $4^{\text {th }}$ of April, 1904 and was followed by a relatively short seismic sequence till the end of 1906. It was preceded by two periods of high seismic activity - an early one in 1893-1894 and a later one in November 1903 [Christoskov et al., 1979]. The Struma fault has not been active since the existence of the Bulgarian seismic network (built in 1981), but it is crossed by many very active faults. The Struma river zone is the most active zone in the studied area.

The Burgas zone (Z9, Figure 1, 2) is in the eastern part of Srednogorie structural province and includes the southern part of Stara Planina, and the Strandzha mountainious area (Bonchev, 1982). The main morphostructure is the Burgas depression. The seismicity is very scarce without any information for historical or recent earthquakes with magnitude greater than 5.0. 


\section{Valentina Protopopova et al.}

The database of earthquake focal mechanisms has been updated by collecting all available solutions till 31 $1^{\text {st }}$ of March, 2018 [Georgiev, 1987; Solakov and Simeonova, 1993; Botev, 2000; Botev et al., 2006; Oncescu et al., 1990; ISC web catalog, EMSC/CSEM web catalog; Dimitrov, 2009; Botev et al., 2014; Protopopova, 2015], and by adding some new solutions, determined by P-wave first motion polarities method (Figure 1). 188 of all fault plain solutions are determined by the authors. Each focal mechanism is evaluated qualitatively, with different weight ratios based on magnitude (stronger earthquakes have higher weight ratio), as the number of first P-wave polarities, and confidence band of the nodal planes have also been considered. The weight coefficients are used in the subsequent stress tensor inversion calculations. The database consists of 366 crustal and 52 mantel earthquakes, and most of the earthquakes are with low to moderate magnitude.

The Vrancea seismic zone (Figure 1) is a unique place on the Earth with continental intermediate focus earthquakes activity (80-160 km depth). It is specific that almost all earthquakes with available focal mechanisms in the Vrancea are reversed. The available focal mechanisms are 52 (only 3 of them are normal faulting), with magnitudes between 4.5 and 7.4 .

In the Negotin seismic zone (Figure 1) the predominant movement is strike-slip. The available focal mechanisms are 18 with magnitudes between $3.5-5.7$ and maximum depth $17 \mathrm{~km} .14$ of the events are located on Serbian territory and are used in stress and strain tensors calculations (12 strike-slip, 1 normal and 1 reversed faulting), and four normal faulting single events on Romanian territory.

The Gorna Oryahovitsa zone (Figure 1) includes 46 focal mechanisms, 29 of them are related with Strajitsa fault system, where the number of normal and trust faulting focal mechanisms is almost equal. The other 17 focal mechanisms are single events, positioned far from each other, they are excluded from stress and strain calculations. All earthquakes are crustal, with depth between $6-28 \mathrm{~km}$, and magnitudes between 2.9-5.7.

The North-Eastern Bulgaria (Figure 1) includes 20 events, 13 of them are related with Provadia fault system (with an almost equal number of normal and trust faulting focal mechanisms), and 7 are situated in the Black Sea (with no predominant faulting). The events in Provadia fault system are related with Mirovo salt deposit, which is in active operation since 1954. All events in North-Eastern Bulgaria are crustal, with depth up to 28 $\mathrm{km}$ and magnitudes between $3.1-4.3$.

The defined focal mechanisms in the Sofia seismic zone (Figure 1) are 42, 20 of them are the mine shock near Pernik city during 2012, followed by 19 stronger aftershocks, and 6 other earthquakes are single events. Almost all earthquakes are with normal faulting (only 8 show trust faulting and two strike-slip). The maximal depth of the earthquakes is around $30 \mathrm{~km}$, with magnitudes between $3.0-5.6$.

Due to the higher seismic activity the Struma seismic zone (Figure 1) includes most of the events with defined focal mechanisms - 114. Only 26 of them show trust faulting. The available focal mechanisms are associated with the main tectonic structures in the zone - Krupnik fault system (40 events) and western positioned focal mechanisms in North Macedonia - Serbo-Macedonian massif (21 earthquakes), Belasitsa horst (29 events), and the focal mechanisms on the Bulgaria-Macedonian border (14 events). The depth of the earthquakes is up to $20 \mathrm{~km}$ and magnitudes are between 2.6 - 5.5.

In the Rodopie massif the defined focal mechanisms are 67, only 13 of them are reversed and 2 strike-slip. The events are divided into four main groups (sub-volumes) - the Mesta river faults (27 earthquakes), the Central Rodopie (24 focal mechanisms), related with Chepino, Dospat and Devin depression fault systems, the Arda river valley (Ardino depression fault system - 9 events), and the South Rodopie slope (7 focal mechanisms). The depth of the earthquakes is up to $20 \mathrm{~km}$ and magnitudes are between 2.5 - 5.3.

In Maritsa zone (Figure 1) the defined focal mechanisms are 54, 19 of them are reversed, and 3 strike-slip. The available focal mechanisms are separated on three mine tectonic structures in the zone - Maritsa river (30 events), Tundzha river (14 events), and Monastery uplifts fault systems (10 events). The number of normal and thrust faulting focal mechanisms in the Monastery uplifts fault system is almost equal (4 normal, 6 reversed). The depth of the earthquakes is up to $20 \mathrm{~km}$ and magnitudes are between $2.8-7.0$. The focal mechanisms of the two catastrophic earthquakes in $1928(\mathrm{M}=6.8$ and $\mathrm{m}=7.0)$ are defined by macroseismic data [Dimitrov, 2009].

In Burgas seismic zone only 4 focal mechanisms are defined, 2 normal and 2 strike-slip, positioned on the European part of Turkey and on the Greece-Turkish border. The earthquakes are again crustal - up to $30 \mathrm{~km}$ depth and of magnitudes between $3.4-4.5$. 


\section{Stress tensor inversion}

The directions of the principal tectonic stress for all seismic zones are determined by the inversion of the focal mechanism data, using the technique of Gephart and Forsyth [1984] and Gephart [1990], which gives the orientation of $\sigma 1, \sigma 2, \sigma 3$ (maximum, intermediate and minimum stress, respectively) and the parameter $\mathrm{R}$, as a measure of relative stress magnitudes [1]. As input data, the principal pressure and tension axes of the focal mechanisms are used. The method for calculating regional stress based on $\mathrm{P}$ and $\mathrm{T}$ axes yield good results when the volume of available focal mechanisms is not from the same source (fault). Each focal mechanism is evaluated qualitatively, with different weight ratios (between 1 - the lowest and 4 - the highest). The higher the weight coefficient, the more times the focal mechanism data are used in the stress tensor inversion calculation.

The best fit stress tensor is the one characterized by the minimum sum of misfit rotation $(\Theta)$, which is the sum of angle of rotation between each observed slip vector and calculated (model) slip vector.

$$
R=\frac{\sigma_{2}-\sigma_{1}}{\sigma_{3}-\sigma_{1}}, 0 \leq \mathrm{R} \leq 1
$$

According to Wyss et al. [1992], the condition of homogeneous stress distribution is fulfilled if the average misfit $\Theta$ is smaller than $6^{\circ}$ and that it is not fulfilled if $\Theta$ is greater than $9^{\circ}$. In the $6^{\circ} \leq \Theta \leq 9^{\circ}$ range, the solution is considered as acceptable, although it may reflect some heterogeneity. The heterogeneity in any data volume is due to the fact that stronger crustal events are usually related to normal faults, but those shallower and weaker are mainly with listric origin. Poor quality focal mechanisms could increase the misfit angle of rotation between observed and model slip vector. As usual, errors come from weaker-low magnitude events, due to the smaller number of P-wave first motion polarities. For the reduction of poor quality focal mechanisms effect, the low magnitude earthquakes are given with lowest weight coefficient and are used only once in the stress tensor inversion calculation. Some of the earthquake focal mechanisms are excluded from the sub-volume data processing (not good quality of the "beach balls", too little or marginal events, focal mechanisms related with other faults/fault systems), because they are leading to unreliable misfits. Also, in some seismic zones the volume of focal mechanisms is separated in sub-volumes (faults, faulting systems, sub-regions).

The results are presented in Table 1, including information regarding the sub-volume (faults, fault systems, subregions) and the number of used focal mechanisms. On Figure 2 the direction of the horizontal projection of the calculated extensional stress axes $\left(\sigma_{3}\right)$ are presented as arrows in all 19 fault systems (only one arrow for Maritsa zone - Maritsa river).

The Vrancea region (Z1) in Romania is characterized by compressional stress regime $\mathrm{R}=0.3$ (Table 1). The maximum compressive stress is orientated horizontally, with north-northwest - south-southeast (NNW-SSE) direction. The extensional component is almost sub-vertical (Figure 2). Similar results are obtained by Polonic et al. [2005]. Oncescu [1987] is defining Vrancea as complex tectonic zone which is characterized by clustered intermediate depth seismic activity, with subduction-type features, although no clear evidences for subduction are observed in the Vrancea region.

In Negotin seismic zone (Z2 - known also as Kraishte zone) the maximum and minimum stress are perpendicular, plunge projections are close to the horizon (Table 1). The compressional axis has northeast-east - southwest-west (NEE-SWW) direction and the extensional axis has NNW-SSE direction (Figure 2). These results can be explained with the predominant strike-slip focal mechanisms.

The Strajitsa fault system, part of the Gorna Oryakhovitza zone (Z2) is characterized by a compressive stress regime, maximum stress is oriented east - west (E-W) and minimum compression is oriented northeast - southwest (NE-SW), (Table 1, Figure 2). The misfit angle is slightly higher than $9^{\circ}$ which shows some heterogeneity of the focal mechanisms volume, probably due to the complicated tectonics of the area.

A compressional stress regime affects also the Provadia fault system in North-Eastern Bulgaria zone (Z3), (Table 1, Figure 2). The minimum stress axis orientation has a NE-SW trend. Similar is the stress regime on Black sea crust but the maximum extension has almost sub-horizontal north - south (N-S) orientation (Figure 2). In both subregions in $\mathrm{Z3}$ the compression is orientated $\mathrm{E}-\mathrm{W}$, probably due to the pressure from east by the oceanic type crust of the Black Sea. 


\begin{tabular}{|c|c|c|c|c|c|c|c|c|c|c|}
\hline Zone & Region & № & $\begin{array}{c}\text { Misfit } 0 \\
{\left[^{\circ}\right]}\end{array}$ & $\mathbf{R}$ & $\begin{array}{c}\sigma_{1 \mathrm{pl}} \\
{\left[^{\circ}\right]}\end{array}$ & $\begin{array}{c}\sigma_{1 \mathrm{az}} \\
{\left[^{\circ}\right]}\end{array}$ & $\begin{array}{c}\sigma_{2 \mathrm{pl}} \\
\left.{ }^{\circ}\right]\end{array}$ & $\begin{array}{c}\sigma_{2 \mathrm{az}} \\
{\left[^{\circ}\right]}\end{array}$ & $\begin{array}{c}\sigma_{3 \mathrm{pl}} \\
\left.{ }^{\circ}\right]\end{array}$ & $\begin{array}{c}\sigma_{3 \mathrm{az}} \\
{\left[{ }^{\circ}\right]}\end{array}$ \\
\hline $\mathrm{Z} 1$ & Vrancea - Romania & 52 & 6.289 & 0.3 & 7 & 338 & 1 & 68 & 83 & 166 \\
\hline $\mathrm{Z} 2$ & Negotin - Serbia/North-Western Bulgaria & 14 & 3.301 & 0.3 & 35 & 238 & 54 & 43 & 7 & 143 \\
\hline $\mathrm{Z3}$ & Gorna Oryahovitsa - Strajitsa & 29 & 9.838 & 0.1 & 23 & 97 & 34 & 351 & 47 & 215 \\
\hline $\mathrm{Z} 4$ & North-Eastern Bulgaria - Provadia & 13 & 8.745 & 0.2 & 11 & 278 & 8 & 187 & 76 & 63 \\
\hline $\mathrm{Z} 4$ & North-Eastern Bulgaria - Black Sea & 7 & 1.986 & 0.3 & 19 & 266 & 70 & 103 & 5 & 358 \\
\hline $\mathrm{Z} 5$ & Sofia seismic zone & 36 & 8.098 & 0.4 & 70 & 250 & 20 & 70 & 0 & 160 \\
\hline $\mathrm{Z} 5$ & Sofia seismic zone - Pernik & 20 & 4.391 & 0.8 & 50 & 260 & 40 & 71 & 4 & 165 \\
\hline $\mathrm{Z} 6$ & Struma zone - Krupnik & 40 & 10.319 & 0.5 & 66 & 196 & 10 & 82 & 22 & 348 \\
\hline $\mathrm{Z} 6$ & Struma zone - Bulgaria-Macedonian border & 14 & 6.743 & 0.5 & 60 & 210 & 29 & 46 & 7 & 312 \\
\hline $\mathrm{Z} 6$ & Struma zone - Belasitsa & 29 & 7.456 & 0.4 & 56 & 255 & 33 & 87 & 5 & 354 \\
\hline $\mathrm{Z} 6$ & Struma zone - North Macedonia & 21 & 8.146 & 0.4 & 70 & 271 & 16 & 54 & 11 & 147 \\
\hline $\mathrm{Z7}$ & Rodopie zone - Mesta river valley & 27 & 6.321 & 0.6 & 51 & 234 & 34 & 88 & 17 & 346 \\
\hline $\mathrm{Z7}$ & Rodopie zone - Central Rodopie & 24 & 6.59 & 0.3 & 53 & 267 & 37 & 89 & 1 & 358 \\
\hline $\mathrm{Z7}$ & Rodopie zone - South Rodopie & 7 & 1.452 & 0.5 & 85 & 314 & 4 & 102 & 3 & 193 \\
\hline $\mathrm{Z7}$ & Rodopie zone - Arda river valley & 9 & 2.481 & 0.5 & 34 & 303 & 45 & 77 & 25 & 195 \\
\hline $\mathrm{Z} 8$ & Maritsa zone - Maritsa river (1) & 30 & 8.709 & 0.7 & 56 & 215 & 11 & 107 & 31 & 10 \\
\hline $\mathrm{Z} 8$ & Maritsa zone - Maritsa river (2) & 26 & 7.914 & 0.6 & 62 & 209 & 9 & 99 & 26 & 4 \\
\hline $\mathrm{Z} 8$ & Maritsa zone - Tundzha river & 14 & 9.575 & 0.6 & 35 & 122 & 40 & 248 & 31 & 8 \\
\hline $\mathrm{Z} 8$ & Maritsa zone - Monastery uplifts & 10 & 6.019 & 0.1 & 0 & 270 & 36 & 180 & 54 & 0 \\
\hline $\mathrm{Z9}$ & Burgas seismic zone & 4 & 0.582 & 0.8 & 41 & 248 & 42 & 106 & 20 & 356 \\
\hline
\end{tabular}

Table 1. Stress tensor inversion results. Z - seismic zones (the same as in Figure 1); Region - area (faults, fault systems, sub-regions) including sub-volume of focal mechanisms; № - number of used focal mechanisms in each region; $\Theta$ misfit rotation angel; R- stress magnitude; $\sigma 1, \sigma 2, \sigma 3$ - maximum, intermediate and minimum stress; pl - plunge angles; az - azimuths.

In the Sofia seismic zone (Z5) the stress regime is normal with north-northeast - south-southwest (NNE-SSW) sub-horizontal orientation of minimum stress (Table 1, Figure 2). The misfit is around $8^{\circ}$ calculated by using all 36 focal mechanism distributed on the Bulgarian part of the zone, which shows some heterogeneity in the volume. For the Pernik fault system, the misfit shows homogeneous stress with same axes orientations like in the Sofia seismic zone, but calculated only with 20 focal mechanisms.

The Struma seismic zone (Z6) is characterized by the highest number of focal mechanisms - more than 100 and very complicated tectonic settings. The high number of available focal mechanisms is divided into four smaller groups related with the most active fault systems in the observed area (Table 1). Although the misfit angles in all four fault systems are pretty high, and show some heterogeneity in calculated stresses, the orientations of the extensional stress axes have similar NNW-SSE directions and almost horizontal plunges (Figure 2). The misfit in Krupnik fault system is grater then $10^{\circ}$, which shows heterogeneity in the volume of focal data. The reason for the high misfit angle could be the complexity of the fault system which could bring in the calculated volume some focal 
mechanisms that belong to other faults. Another reason could be the presence of errors in focal mechanism solutions (26 of all earthquakes in the volume are with magnitude between 2.8 - 3.5). For misfit reduction the available mechanisms volume should be additionally tested or recalculated which is done only for 10 of them (calculated by the authors).

Normal stress regime is characterizing all fault systems in Rodopie mountain massif (Z7). The available focal mechanisms are separated into four groups: Mesta river fault system, Central Rodopie fault systems, Arda river fault system and fault systems on southern slope of Rodopie massif in Northern Greece. The stress regimes in all sub-zones are normal, with good homogeneity of the calculated stress but it is interesting that the extensional axes are slightly changing their directions from NNW-SSE for western part of the zone to NNE-SSW for the central and eastern parts (Table 1, Figure 2).

In the Maritsa seismic zone (Z8), the stress tensor is calculated in the Maritza river, the Tundzha river and the Monastery uplifts fault systems (Table 1).

Due to the high misfit in the rotation angle of the calculated stress, it was necessary to reduce the initial number of available focal mechanisms (30) in the Maritsa river faults system. Four mechanisms located in the lower riverside of the Maritsa river have been excluded from the stress calculations but still the stress shows some heterogeneity. In both cases the stress regime is extensional with almost NNE-SSW orientation (Figure 2). The same stress regime is calculated for the Tundzha river fault system, with a misfit higher than $9^{\circ}$ and pretty small amount of focal mechanisms (only 14). The reason for the misfit here is probably the large area of the event distribution, so the stress could be different on both sides. The dominant stress regime in Monastery uplifts faults system is compressional with horizontal maximum stress in $\mathrm{E}-\mathrm{W}$ direction, but the extensional axis is oriented in $\mathrm{N}-\mathrm{S}$ direction with plunge $54^{\circ}$ (Figure 2).

In the Burgas seismic zone (Z9) the stress regime is normal with N-S minimum stress orientation (Table 1, Figure 2). The compressional stress here again has an $\mathrm{E}-\mathrm{W}$ trend as in $\mathrm{Z3}$, probably due to pressure from the east by the oceanic Black Sea plate. The calculated stress is not absolutely plausible due to the only limited number of available focal mechanisms- only four, positioned far from each other. This number of data is the minimum amount for inversion calculation.

Based on the obtained results for the studied area, it can be concluded that the extension is increasing from north to south (decreasing of the plunge angle) and changing the stress trend (azimuth) from NNW-SSE for western part of the observed area, to NNE-SSW trend for eastern part. The Black Sea plate is causing pressure from east to the continental Earth crust, which affects the maximum stress directions (E-W) in seismic zone near the coast.

\section{Strain tensor inversion - deformation}

The strain field is analyzed with the estimation of the orientation of the principal strain axes. The released deformation is computed from the moment tensors of the focal mechanisms, according to the relation developed by Kostrov [1974]:

$$
\varepsilon_{i j}=\frac{1}{2 \mu V} \sum_{k} M_{i j}^{k}
$$

Where $\mu$ is rigidity modulus ( $3 \times 10^{10} \mathrm{~Pa}$ ); $V$ is crustal volume (the thickness of the crust by the area affected by the earthquakes); $M_{i j}^{k}$ is the moment tensor of the $k$-th earthquake. The moment tensor is related to the scalar seismic moment by:

$$
M_{i j}^{k}=M_{0}^{k}\left(u_{i}^{k} n_{j}^{k}+u_{j}^{k} n_{i}^{k}\right)
$$

where $u_{i}^{k}$ is a unit vector normal to the fault plane and $u_{j}^{k}$ is a unit vector parallel to the slip direction. The scalar seismic moment is computed from the magnitude with the relation by Riznichenko [1985]:

$$
\log M_{0}=1.6 M+8.4 \pm 0.5
$$




\section{Valentina Protopopova et al.}

It is very hard to estimate the exact volume that is affected by every earthquake or group of earthquakes. This is why the tensor of deformation is calculated only as principal strain axes directions, not as absolute measure. The crustal thickness on the territory of Bulgaria varies between 30 and $50 \mathrm{~km}$ [Georgieva and Nikolova, 2013]. The depth of the Moho boundary is about $30 \mathrm{~km}$ beneath Northern Bulgaria (Negotin, Gorna Oryahovitsa and NorthEastern Bulgaria) and Upper-Thracian valley (Maritsa and Burgas seismic zones). The crust is thickening beneath the Rhodopie massif and Pirin Mountain where it reaches about $50 \mathrm{~km}$. The Moho structure in the South-Western Bulgaria is very complex and reaches around $30 \mathrm{~km}$ (Sofia and Struma seismic zones). The crustal thickness under Vrancea is around $42 \mathrm{~km}$ [Ivan, 2011] but the observed seismicity is between 80-160 km depth, realized in Earth mantle, and for that reason the deformation in the Vrancea seismic zone is not calculated. The area affected by earthquakes is evaluated approximately (square or rectangular boundaries around every fault systems).

The computed orientations of the principal axes of the strain tensor are shown in Table 2 and are plotted in Figure 3A. In Figure 3 the results of the Sofia seismic zone - Pernik fault (Z5) are excluded, because all 20 focal mechanisms from this sub-volume are used in strain calculation of the Sofia seismic zone (Z5), calculated with 36 focal mechanisms. The Maritsa zone - Maritsa river $(1, \mathrm{Z} 8)$ is also excluded due to the higher misfit in stress calculation using all 30 focal mechanisms, results in the Maritsa zone are plotted - the Maritsa river (2) made by 26 focal mechanisms.

\begin{tabular}{|c|c|c|c|c|c|c|c|c|}
\hline Zone & Region & № & $\begin{array}{c}\boldsymbol{\varepsilon}_{1 \mathrm{pl}} \\
{\left[^{\circ}\right]}\end{array}$ & $\begin{array}{c}\varepsilon_{1 \mathrm{az}} \\
{\left[{ }^{\circ}\right]}\end{array}$ & $\begin{array}{c}\varepsilon_{2 p l} \\
{\left[{ }^{\circ}\right]}\end{array}$ & $\begin{array}{c}\varepsilon_{2 \mathrm{az}} \\
{\left[^{\circ}\right]}\end{array}$ & $\begin{array}{c}\left.\varepsilon_{3 p l}\right] \\
{\left[{ }^{\circ}\right]}\end{array}$ & $\begin{array}{c}\varepsilon_{3 \mathrm{az}} \\
{\left[^{\circ}\right]}\end{array}$ \\
\hline $\mathrm{Z} 2$ & Negotin - Serbia/North-Western Bulgaria & 14 & 27 & 230 & 79 & 18 & 17 & 140 \\
\hline $\mathrm{Z3}$ & Gorna Oryahovitsa - Strajitsa & 29 & 43 & 133 & 33 & 260 & 30 & 12 \\
\hline $\mathrm{Z} 4$ & North-Eastern Bulgaria - Provadia & 13 & 16 & 264 & 57 & 168 & 60 & 51 \\
\hline $\mathrm{Z} 4$ & North-Eastern Bulgaria - Black Sea & 7 & 34 & 113 & 33 & 220 & 47 & 337 \\
\hline $\mathrm{Z} 5$ & Sofia seismic zone & 36 & 60 & 266 & 31 & 57 & 14 & 155 \\
\hline $\mathrm{Z} 5$ & Sofia seismic zone - Pernik & 20 & 55 & 240 & 37 & 70 & 6 & 165 \\
\hline Z6 & Struma zone - Krupnik & 40 & 80 & 134 & 3 & 235 & 10 & 325 \\
\hline $\mathrm{Z} 6$ & Struma zone - Bulgaria-Macedonian border & 14 & 70 & 120 & 14 & 248 & 7 & 340 \\
\hline Z6 & Struma zone - Belasitsa & 29 & 66 & 144 & 4 & 48 & 16 & 317 \\
\hline Z6 & Struma zone - North Macedonia & 21 & 81 & 138 & 0 & 230 & 10 & 320 \\
\hline $\mathrm{Z7}$ & Rodopie zone - Mesta river valley & 27 & 44 & 22 & 50 & 230 & 11 & 330 \\
\hline $\mathrm{Z7}$ & Rodopie zone - Central Rodopie & 24 & 240 & 32 & 103 & 19 & 2 & 50 \\
\hline $\mathrm{Z7}$ & Rodopie zone - South Rodopie & 7 & 300 & 2 & 94 & 13 & 185 & 88 \\
\hline $\mathrm{Z7}$ & Rodopie zone - Arda river valley & 9 & 337 & 4 & 96 & 17 & 188 & 83 \\
\hline $\mathrm{Z} 8$ & Maritsa zone - Maritsa river (1) & 30 & 54 & 40 & 324 & 55 & 167 & 16 \\
\hline $\mathrm{Z} 8$ & Maritsa zone - Maritsa river (2) & 26 & 58 & 42 & 318 & 44 & 177 & 25 \\
\hline $\mathrm{Z} 8$ & Maritsa zone - Tundzha river & 14 & 66 & 39 & 320 & 60 & 167 & 27 \\
\hline $\mathrm{Z} 8$ & Maritsa zone - Monastery uplifts & 10 & 282 & 58 & 182 & 30 & 24 & 7 \\
\hline Z9 & Burgas seismic zone & 4 & 237 & 31 & 114 & 16 & 15 & 45 \\
\hline
\end{tabular}

Table 2. Strain tensor inversion results. Z - seismic zones (same as in Figure 1), Region - area (faults, faulting systems, sub-regions) including sub-volume of focal mechanisms, № - number of used focal mechanisms in each region, $\varepsilon 1, \varepsilon 2, \varepsilon 3$ - principal strain axes, pl - plunge angles, az - azimuths. 

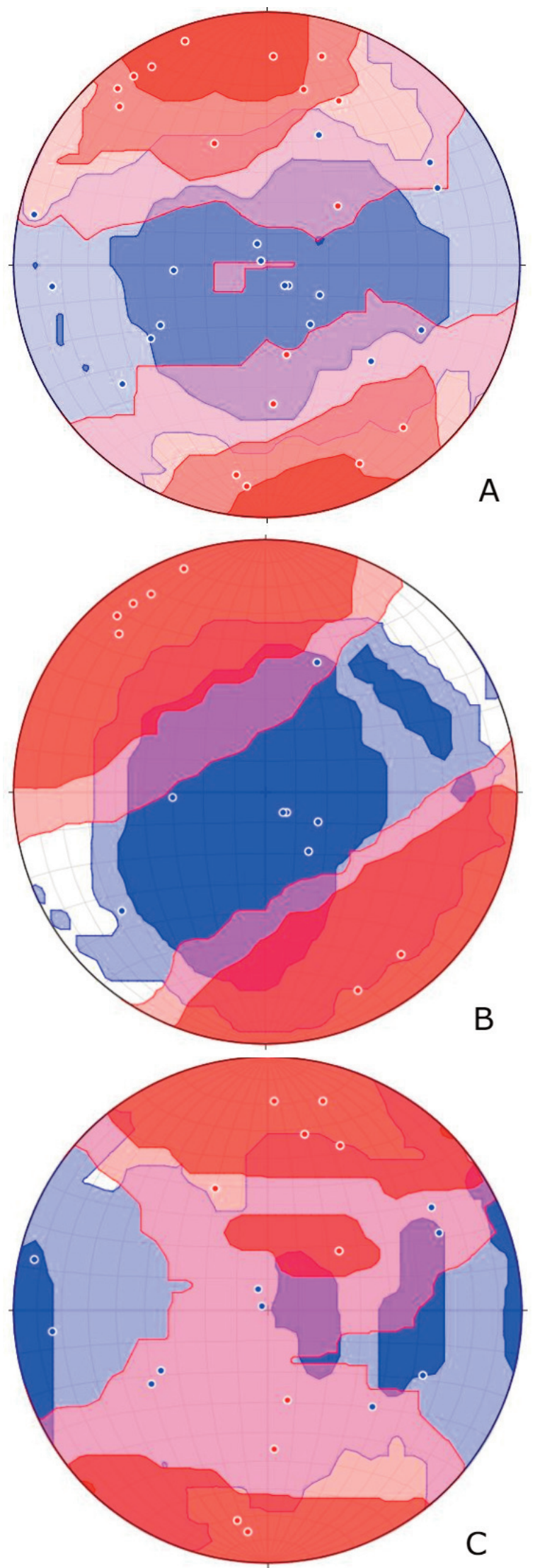

Figure 3. The principal strain axes $\varepsilon 1$ and $\varepsilon 3$ in: A. seismic zones Z2-Z9, and the regions (from Table 2), except Sofia seismic zone - Pernik and the Maritsa zone - Maritsa river (1); B. Z2, Z5, Z6, Z7 - Mesta river valley; C. Z3, Z4, Z7 - the Central Rodopie, Z7 - the South Rodopie, Z7 - the Arda river valley, Z8, Z9. 


\section{Valentina Protopopova et al.}

Figure 3A shows that the deformation clearly marks two directions - horizontal almost in north-south and vertical, but the confidence bands are overlapping in some areas, which are marking heterogeneity of the Earth crust strain.

In order to understand better the reason for heterogeneity, the calculated deformations are divided in two groups - results obtained in the Western Bulgaria including results in Z2, Z5, Z6 and Z7 (only the Mesta river valley) (Figure 3B) and results obtained in the Eastern Bulgaria, including results in Z3, Z4, Z7 (the Central and the South Rodopie, and the Arda river valley), Z8 and Z9 (Figure 3C). The variation of the stress trend from NNW-SSE for western part of the observed area to NNE-SSW trend for eastern part could affect the strain. In Western Bulgaria the strain shows horizontal component with NNW-SSE direction and vertical (Figure 3B) similar as stress directions. In Eastern Bulgaria deformations are more complicated as horizontal strain exists in N-S and also E-W directions, and insignificant vertical strain (Figure 3C).

It should be pointed out that the stress tensors obtained from inversion of the focal mechanisms are computed by minimizing differences between observed and resolved slip directions, while the strain tensors for each zone (Table 2) are evaluated directly from the observed data. The stress tensor is related to the regional stress field while the strain is related only to seismic deformation and not to the overall regional tectonic field. Although, the regional tectonic stress is the reason for the stronger earthquakes and it has the same N-S and vertical directions as the strain, except near the Black Sea coast, where the direction is E-W. The deformation results could be affected much more by poor quality focal mechanisms than stress tensor calculation, because no weight coefficient here are applied.

The comparison between the obtained stress and strain tensors gives evidence that the direction of the principal stress axes and the principal strain axes are not exactly the same throughout the considered zones. This discrepancy suggests that the stress field is much more heterogeneous because the crust is not uniform in strength [Wyss et al., 1992].

\section{Conclusion}

In general, for the territory of Bulgaria predominant horizontal extension in north-south exists (according to the defined principle axes of the regional stress tensors - Figure 2), which corresponds well with the formation of depression structures with east-west direction, (Z5), the Sofia valley in the Sofia seismic zone (Z5), the Simitli and the Struma valleys in the Struma seismic zone (Z6), the Upper Thracian valley in the Maritsa seismic zone (Z8), and others. The extension does not coincide with the basic morpho-structures but lies across them suggesting a relatively young stage of deformation [Botev, 2000, Botev et al., 2006]. The extensional processes are more significant in the Western Bulgaria and especially in the South-Western Bulgaria, where the decompression axes of the defined stress tensors are almost horizontal and have a slight orientation to the north-northwest - south-southeast. Stress tensors from the central to the eastern part of the observed area alter the directions of the decompression axes towards the north-northeast - south-southwest direction, and a partition in the orientation of extensive stresses in the central part of the country. At the same time, it has zones with local areas of relative compression, probably due to differences in the relative movement of individual faults. For example, in the North-Eastern Bulgaria the horizontal extension is very small but the compression is dominant. In the Vrancea seismic zone, a significant compression is realized in the near-horizontal direction, which probably marks the palaeosubduction characteristics of the seismic zone.

The GPS measurements in last years [McClusky et al., 2000; Georgiev et al., 2007; Georgiev et al., 2013; Mouslopoulou, 2014] have shown that the largest horizontal movements (about $35 \mathrm{~mm} / \mathrm{yr}$ ) are recorded in the central and the southern part of the Aegean area. Measurements in Northern Greece show significantly lower velocities in the southern direction (9-11 mm/yr), while in South-Western Bulgaria velocities are about 3-4 mm/yr. According to the same authors, several measuring points in North-Eastern Bulgaria demonstrate lower speeds (1-2 mm / yr) of movement in a similar direction. The significant difference in the speed of movement indicates the existence of an extension province in the region of North Aegean Greece. According to Burchfiel et al. [2006], the Southern Bulgaria and the Northern Greece define the South Balkan Extensional Region. The northern boundary of the Aegean extensional region passes through the Central Bulgaria (Stara planina Mountain) and the analysis of the active faulting has indicated that huge part of the Balkan peninsula has been characterized by extensional tectonism. 
The main result from the focal mechanism, stress and deformation tensors analysis is the prevalence of a normal - extensional stress regime in almost all seismic zones with augmentation from north to south. These results confirm the hypothesis that the neotectonic movements in Balkan peninsula region are consequence of the long lasting extensional movements in the inner parts of the Aegean and Central Balkan regions [Burchfiel et al., 2006], and are in agreement with the newly obtained model for present day kinematics of the Central and Eastern Mediterranean [Pérouse et al., 2012]. The observed misfit between the principal axes of the obtained stress and strain tensors could be explained by the consideration of Wyss et al. [1992] that the crust is not uniform in strength, and if there are planes of low shear strength or zones of weakness, like preexisting faults, the orientations of the principal axes of stress and strain may differ substantially. However, it must also be taken into consideration that the stress tensor is related to the regional stress field, while the strain tensor is estimated directly from observed seismic data.

Acknowledgements. The authors would like to express their gratitude for the financial support to:

- The Project for young scientist 2017 - "Assessment and analysis of stress and deformation of Earth crust in seismic zones in Bulgarian territory and adjacent lands", 2017-2019, financed by the Bulgarian Academy of Sciences.

- COST is supported by the EU Framework Program Horizon 2020.

- Grand DN 14-1/11.12.2017 - supported by the Bulgarian National Science Fund.

\section{References}

Barrier, E., N. Chamot-Rooke and G. Giordano (2004). Geodynamic map of the Mediterranean, Sheet 1- Tectonics and Kinematics, CGMW, France.

Botev, E. (2000). On the Seismotectonics of the Bulgarian territory, Final Report N236 / ICPT Program for training and research in Italian laboratories. Trieste, Italy, $87 \mathrm{pp}$.

Botev, E., I. Georgiev and D. Dimitrov (2006). Recent seismicity, stress and strain in South-western Bulgaria, Geodesy 17, BAS, 53-68.

Botev, E., V. Protopopova, I. Aleksandrova, B. Babachkova, S. Velichkova, I. Popova, P. Raykova and M. Popova (2014). Data and analysis of the events recorded by NOTSSI in 2014, Bulg. Geophys. J., Sofia, 40, 98-108.

Bonchev E., V. I. Boune, L. Christoskov, J. Karagjuleva, V. Kostadinov, G. J. Resner, Sn. Rizhikova, N. V. Shebalin, V. N. Sholpo, D. Sokerova (1982). A method for compilation of seismic zoning prognostic maps for the territory of Bulgaria. Geologica Balcanica,12, 2, 3-48.

Burchfiel, B. C., R. W. King, A. Todosov, V. Kotzev, N. Durmurdzanov, T. Serafimovski and B. Nurce (2006). GPS results for Macedonia and its importance for the tectonics of the Southern Balkan extensional regime, Tectonophys, 413(3-4), 239-248.

Christoskov L, D. Sokerova, Sn. Rizhikova (1979). New catalogue of the earthquakes in the territory of Bulgaria and adjacent region for the period V century BC to XIX century, Archives of the Geophysical Institute of BAS, Sofia.

Christoskov, L., R. Glavcheva, Tz. Georgiev Tz. Christova, K. Donkova, S. Simeonova, D. Solakov, S. Dineva, D. Mihaylov, B. Dimitrov, E. Spassov (1988): Seismological features of the region of the 1986 earthquake sequence, Bulg. Geophys. J., 14 (2), 73-89.

Dimitrov, D. (2009). Geodetic studies of seismogenic zones, CGLBG-BAN, Dissertation work for obtaining the scientific degree dtn. (in Bulgarian).

Georgieva, G. and S. Nikolova (2013). The Moho depth and crustal structure beneath Bulgaria obtained from receiver function analysis, Comptes Rendus de l'Academie Bulgare des Sciences, 66, 5, 725-732.

Grigorova E., D. Sokerova, L. Christoskov, Sn. Rizhikova (1979). Catalogue of the earthquakes in the territory of Bulgaria for the period 1900-1977., Archives of the Geophysical Institute of BAS, Sofia.

Georgiev, I., D. Dimitrov, T. Belijashki, L. Pashova, S. Shanov and G. Nikolov (2007). Geodetic constraints on kinematics of southwestern Bulgaria from GPS and leveling data, Geological Society, London, Special Publications, 291: 143-157.

Georgiev, I., D. Dimitrov, E. Botev (2013). Crustal Motion Monitoring in Bulgaria and Surrounding Regions by Permanent GPS Array, Proceedings of the 7th Congress of Balkan Geophysical Society - Tirana, Albania, 7-10 October. 


\section{Valentina Protopopova et al.}

Georgiev, Tz. (1987). Fault plane solutions, pressure and tension axes for some earthquakes in SW Bulgaria. Bulg. Geophys. J.,13, N3, 102-108.

Gephart, J. W. and D. W. Forsyth (1984). An improved method for determining the regional stress tensor using earthquakes focal mechanism data: Application to the San Fernando earthquake sequeance, J. Geophys. Res., 89, 9305-9320.

Gephart, J. W. (1990). FMSI: A FORTRAN program for inverting fault/slickenside and earthquake focal mechanism data to obtain the regional stress tensor, Comput. Geosci., 16, 953-989.

Ivan, M. (2011). Crustal thickness in Vrancea area, Romania from S to P converted waves, J. Seismol., Springer Verlag, $15,2,317-328$.

Jackson, J. and D. P. McKenzie (1984). Active tectonics of the Alpine-Himalayan Belt between western Turkey and Pakistan, Geophys. J.R. Astr. Soc., 77, 185-246.

Jackson, J. and D. P. McKenzie (1988). The relationship between plate motions and seismic moment tensors, and the rates of active deformation in the Mediterranean and Middle East, Geophys. J. Int., 93, 45-73.

Jackson, J. (1992). Partitioning of strike-slip and convergent motion between Eurasia and Arabia in eastern Turkey, J. Geophys. Res.: Solid Earth, 97, B9, 12471-12479.

Jackson, J. (1994). Active tectonics of the Aegean region, Ann. Rev. Earth Planet. Sci., 22, 239-71.

Kostrov, B. V. (1974). Seismic moment and energy of earthquakes and seismic flow of rock. Izv. Acad. Sci. USSR Phys. Solid Earth, Engl. Transl., 1, 23-44.

McClusky, S., S. Balassanian, A. Barka, C. Demir, S. Ergintav, I. Georgiev, O. Gurcan, O. Hamburger, K. Hurst, H. Kahle, K. Kastens, G. Kekelidze, R. King, V. Kotsev, O. Lenk, S. Mahmoud, A. Moshin, M. Nadariya, A. Ouzounis, D. Paradissis, Y. Peter, M. Prilepin, R. Peilnger, I. Sanli, H. Seeger, A. Tealeb, M. Toksoz and G. Veis (2000). Global Positioning System constraints on plate kinematics and dynamics in the eastern Mediterranean and Caucasus, J. Geophys. Res.: Solid Earth, 105, B3, 5695-5719.

McKenzie, D. P. (1970). Plate tectonics of the Mediterranean region, Nature, 226, 239-243.

Mouslopoulou, V., V. Saltogianni, M. Gianniou and S. Stiros (2014). Geodetic evidence for tectonic activity on the Strymon Fault System, northeast Greece, Tectonophysics, 633, 246-255.

Oncescu, M. C., C. I. Trifu, T. Hristova, S. Simeonova and D. Solakov (1990). A detailed analysis of the Strazhitsa (Bulgaria) seismic sequences of 1986: location, focal mechanism and regional stress tensor, Tectonophysics, $172,121-134$.

Oncescu, M. C. (1987). On the stress tensor in Vrancea region, J. Geophysics, 62, 62-65.

Papazachos, B. C., P. E. Comninakis, G. F. Karakaisis B. G., Karakostas, Ch. A. Papaioannou, C. B. Papazachos, E. M. Scordilis (2000). A Catalogue of Earthquakes in Greece and Surrounding Area for the Period 550BC - 1999. http://geohazards.cr.usgs.gov/iaspei/europe/greece/the/catalog.htm.

Pérouse, E., N. Chamot-Rooke, A. Rabaute, P. Briole, F. Jouanne, I. Georgiev and D. Dimitrov (2012). Bridging onshore and offshore present-day kinematics of central and eastern Mediterranean: Implications for crustal dynamics and mantle flow, Geochem. Geophys., Geosyst., 13(Q09013), 25.

Polonic, G., D. Zugravescu and V. Negoita (2005). The present-day stress field pattern in the Eastern Carpatian bend area, Rev. Roum, Bucuresti, Geophysique, 49, 3-30.

Protopopova, V. (2015). Geodynamics of the Bulgaria territory and adjacent lands by seismological data, $\mathrm{PhD}$ Abstract, National Institute of Geophysics, Geodesy and Geography, Bulgarian Academy of Sciences (in Bulgarian).

Riznichenko, J. V. (1985). Problems of seismology, Moscow, Science, 406 (in Russian).

Solakov, D. and S. Simeonova (1993). Bulgaria catalogue of earthquakes 1981 - 1990. Bulgarian Academy of Sciences, Geophysical institute, Seismological department.

Tzankov, Tz. and G. Nikolov (1998). Contemporary geodynamic aspects of Bulgarian geodesy. In: Proceedings of the Symposium "50 years of CLHG in Bulgaria”, Sofia, 53-62, (in Bulgarian)

Tsenov, L. and E. Botev (2007). Earthquake hazard and seismic risk mitigation. Consequences of earthquakes at the end of the 20th century in Bulgaria, 2nd National Scientific and Practical Conference on Emergency Management and Protection of the Population, Sofia, November 9, proceedings 234-244. (in Bulgarian).

Vatsov, S., 1902. Earthquakes in Bulgaria in the 19th Century. CM See, S., DP, 1-93.

Wyss, M., B. Liang, W. R. Tanigawa and W. Xiaoping (1992). Comparison of orientations of stress and strain tensor based on fault plane solutions in Kaoiki, Hawaii, J. Geophys. Res., 97, 4769-4790. 
Zagorchev, I. (1992). Neotectonics of the central parts of the Balkan peninsula: basic features and concepts. Geologische Rundschau, 81, 3, 635-654.

Zagorchev I. (1996). Late Alpine (Paleogene-earliest Neogene) and neotectonic development of the central parts of the Balkan peninsula. Zeitschrift der Deutcher Geologischen Geselschaft, 24, 1-2, 91-112.

International Seismological Centre, On-line Bulletin, http://www.isc.ac.uk, Internatl. Seis. Cent., Thatcham, United Kingdom (2013).

EMSC/CSEM - European-Mediterranean Seismological Centre, http://www.emsc-csem.org/. 